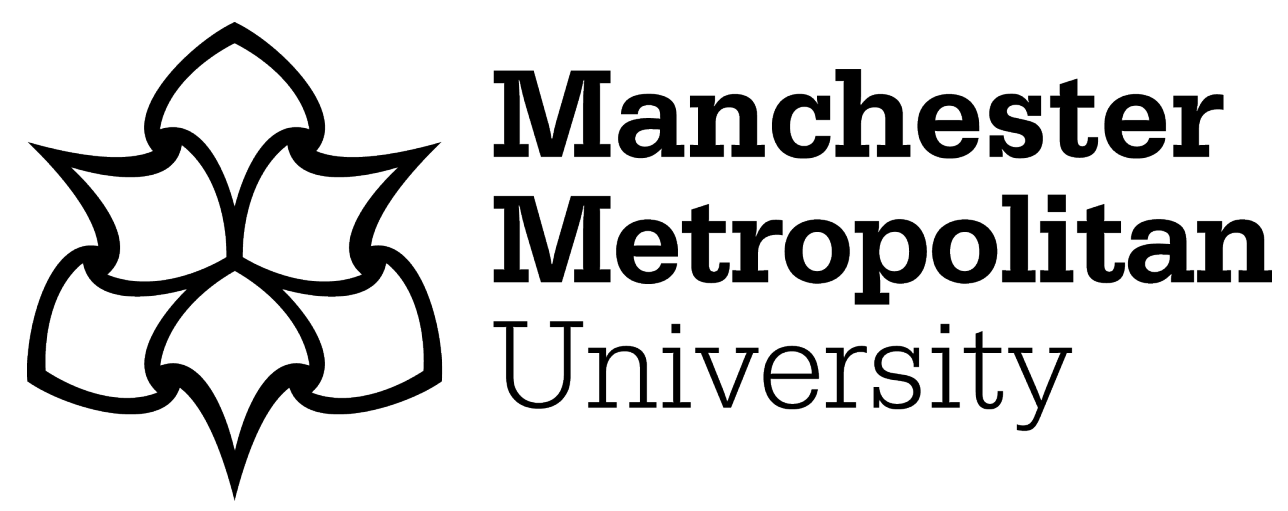

de Freitas, Elizabeth (2020) Science studies and the metamorphic multiple earth: Bruno Latour's risky diplomacy. Cultural Studies - Critical Methodologies, 20 (3). pp. 203-212. ISSN 1532-7086

Downloaded from: https://e-space.mmu.ac.uk/623999/

Version: Accepted Version

Publisher: SAGE Publications

DOI: https://doi.org/10.1177/1532708619880220

Please cite the published version 


\title{
Science studies and the metamorphic multiple earth: Bruno Latour's risky diplomacy
}

\author{
Accepted in Cultural Studies-Critical Methodologies, \\ Sage Journal, September 2019 \\ Elizabeth de Freitas \\ 1.de-freitas@mmu.ac.uk \\ Education and Social Research Institute \\ Manchester Metropolitan University
}

\begin{abstract}
This essay focuses on Bruno Latour's recent attempts to study the metamorphic rone of terrestrial life, within the current climate crisis and environmental "cosmocolossus". I explore his proposal for a risky diplomacy in the Anthropocene "end times", as a way of dealing with the increasingly tense relations between polarized and weaponized perspectives. I show how his work continues to seek a form of scientific practice that involves the invention of equipment (apparatus) that make perceptible (principally to humans) the existence of non-human agencies, thereby expanding the opportunities for alliances and a pluralist ecology, and ultimately assembling another more-than-human political body. I also discuss critiques and concerns regarding the specifics of this proposal.
\end{abstract}




\section{Science studies and the metamorphic multiple earth: Bruno Latour's risky diplomacy}

\section{Introduction}

Bruno Latour has been pursuing an anthropology of the Moderns for over thirty years, and been hugely instrumental in Science Studies, shaping the field in the early 1980s (Latour, 1987, 1988). Long before the 'ontological turn' and the 'new materialisms' (Coole \& frost, 2010), Science Study scholars in the 1980s showed how scientific practice was always engaged with the more-than-human, troubling the subject/object divide in any experiment with "consequential meaning", by engaging nonhuman "actants" with varying degrees of agency.

The 2017 book Facing Gaia: Eight lectures on the new climatic regime offers a fascinating synthesis of his efforts over the last decades to find the experience at the heart of Modernity, develop an alternative to that misguided mode of being, and map a new way of worlding in the midst of our ecological crisis. ${ }^{1}$ In focusing on the metamorphic zone of terrestrial life, he demands that there be a reckoning with our current climate crisis and environmental "cosmocolossus". The book dwells on the many facets of this task, distinguishing the globe from the earth, Gaia from religion, climatology and geostory from geology, and the Anthropocene from Modernity.

In this essay, I will explore (a) the use of the term "climatic regime" and the complex notion of the Anthropocene, (b) Latour's emphasis on agency, animacy, and immanence as part of his "practical metaphysics", (c) his proposal for a risky terrestrial diplomacy and compositional peace under post-truth conditions, and (d) the way in which the "end times" is conceived as part of a new historicity and spatial imaginary. These topics together link his ontological commitments with his interest in the politics of knowledge-pursuing practices. Latour proposes a kind of posthuman diplomacy for the "end times" as a way of dealing with the increasingly tense relations between various polarized and weaponized perspectives during the Anthropocene. Such an endeavour involves a remixing of politics and earth, reckoning with the specific historical challenges we face today. In this essay I dig into the ontological commitments underpinning Latour's image of science, and I explore the political implications of his proposal for an Anthropocene diplomacy that embraces "a Politics in which the role of Nature is explicit" (Latour, 2017, p. 47)." Elsewhere I have discussed his endorsement of speculative fiction in this endeavor (de Freitas, 2017a), as well as his work on rethinking quantitative methods (de Freitas, 2016a).

Latour's image of science is gleaned from anthropological studies of scientific activity. Through careful ant-like tracing of the actions of scientists, we can see that scientists work in a metamorphic mixture that subsumes human agency, a shapeshifting transactional zone where traits are exchanged and power is negotiated. Actor-network-theory (ANT) was meant to show how scientists have never been Modern, but have always been immersed in the relational space of multiplying agencies. Such practice is attuned to the metamorphic zone of more-than-human becoming. When scientists reject this 'anthropological' image of

1 The 2018 Down to earth: Politics in the new climatic regime is not quite as powerful, although it offers insight into the same content and argument.

2 Latour points out that the account of 'Galileo the renegade' is now used by climate skeptics when they attack the apparent consensus of climatologists. 
science, because it seems to undermine claims to objectivity, they fail to realize that multiplying agency is their strength!

The clear result of the scientific disciplines is an immense increase in what moves, acts, heats up, boils over, and becomes complicated - in sum, in what actually animates the agents that constitute the world and in the continuous refinement of the metamorphic zone that we encountered in the earlier lectures."(italics in original, Latour, 2017, p. 163).

According to Latour, science aims to uncover agencies, ensuring that claims about particular competencies on behalf of the characters involved (volcanoes, bacteria, electrons) are entirely ground in the relational performances of those characters. In other words, science, as it is practiced or as it should be practiced, is focused on creating opportunities or experiments that reveal nonhuman agency, and thereby making visible new forms of life. Latour affirms the power of science as a practice that is committed to understanding the plurality and generativity of the earth. It is this political power of science to "represent" underrepresented others, not in the way the nation state or other forms of governance do, but through a strange system of experimentation, inference and proof, which is crucial today in the current climatic regime: "That power of representation will be of capital importance in the coming conflicts over the form of the world and the new geopolitics." (Latour, 2017, p.33).

In a 'post-truth' era, Latour is explicit - we must defend scientific inquiry. He is extremely clear, however, that he is not defending science in the name of white Euroexceptionalism, but rather as a particular material and worlding practice that aims to responsibly encounter the more-than-human. Latour is adamant that science studies was never anti-science (as it was sometimes interpreted), but was simply affirming the political project of science. Crucial to his early work, and still strongly articulated in recent publications, is his description of how science works: it involves the invention of equipment (apparatus) that make perceptible (principally to humans) new forms of non-human sign-making and agency, thereby multiplying agencies across an ecology, expanding the alliances, and ultimately assembling another more-than-human political body. Consider, for instance, the way that the human body is now known (to humans) as a quivering bacterial colony, sustained through various risky alliances and cross-species entanglements.

Thus Science Studies for Latour is not simply a critique of false claims to objectivity, nor driven only to disclose the relativism and bias of scientific truth, but rather aims to show how science gains in realism through this multiplying of agency. Unlike relativists who banish the ontological realm, he claims that the metamorphic zone "is a property of the world itself and not only a phenomenon of language about the world."(Latour, 2017, p. 69). This is not the "pseudo-realism" that purports to describe the actor (human or other) as intentionally moving about, while the context (earth or other) lies inert in the background. Latour's 'realism', like Barad's agential realism, is deeply committed to the entanglement of body, place, and idea. To be entangled is more than simply recognizing the relativism of truth claims, nor is it merely a reference to the situated nature of knowledge; entanglement is about the ontology of relationality. And it is this realist ontology (of dependence relations) that science (at its best) pursues and elaborates.

\section{Anthropocene, Capitalocene, Anthrobscene, Plantationocene, ...}


The term "Climatic regime" reminds us that "the climate" is never a pure state of nature operating outside of culture, but always populated and engendered by diverse agencies, some of them human (Verlie, 2017). Granted, the "New Regime" of the Anthropocene entails extensive power for particular humans, as is evident in the geologic record (the global distribution of plastics, etc), and points us towards terms like Capitalocene (Moore, 2015) and Anthrobscene (Parikka, 2015) and Plantationocene (Tsing, 2017). For Latour (2017), the coming ecological crisis entails "a profound mutation in our relation to the world" and a new image of humanity (p.8). And this mutation demands new ways of "belonging to nature". In the first two book chapters, Latour revisits the notion of 'nature' inherited from Anthro-centric Moderns, a notion that was used to unify the polity and 'naturalize' law. Any claims to such an essentialized Nature today are more often - and rightly - contested. Latour confesses that his own contribution to this critique of 'natural kinds' has doubtless played some part in assisting the adversaries and deniers of climate science, who are all too happy to cast doubts on the facts that confirm the human origin of current climate mutation (Alumkal, 2017; Drummond \& Fischhoff, 2017). Notably, many of these skeptics are aligned with neoliberal and conservative religious beliefs, and dismiss science as 'politically motivated' if it curtails the flow of capital (Gauchat, 2012; Hamilton, 2010). Latour is now concerned with these science deniers, in the midst of the ecological crisis.

The Anthropocene sets the stage for a science that must confront its Western imperialism in ways that stretch beyond reflexive critique (Avelar, 2013; Stengers, 2015, 2018). This new science might involve a kind of geohistory or geostory to serve the earthbound "terrans" who have forgotten that their planetary dwelling is also a living creature (Stengers, 2018). But the old "white geologies" encode within them an extractive logic that is precisely what has caused so much destruction. Povinelli (2016) suggests we focus on "geontologies" and resist a particular European image of humanity that fails to reckon fully with the pressing problematic of non-life (the geo). Geontopower characterizes that which is both at work and unravelling today, if one were to do history and politics and science as earthbound terrans rather than globalizing Moderns, and confront the 'end-times' of a particular biosphere. She chooses "geo" because of its reference to "nonlife" and because it illuminates "the cramped space in which my indigenous colleagues are forced to maneuver as they attempt to keep relevant their critical analytics and practices of existence." (p.6).

Insofar as the Anthropocene marks a period when "all human activity" has been transformed into earthly mutations, and when the climate stability of the Holocene comes to an end, its essential to note that this moment has been manufactured by a portion of humanity invested in accelerated capitalist accumulation and white supremacy. Latour affirms the 1610 date as a possible marker for the beginning of the Anthropocene, because "the reforestation of the American continent had, by that date, led to the stocking of so much atmospheric $\mathrm{CO} 2$ that climatologists could use it as a minimum quantity on the basis of which they could measure its regular increase. But why this massive reforestation? ... because of the extermination by the sword, but also by contagion and disease, of nearly fiftyfour million Native Americans ..." (p.184-185). Understanding this 'global' condition as the legacy of European imperialism is important, and it's also important to understand how its unraveling (Chakrabarty, 2014). There simply is no one humanity that suffers the Anthropocene, but a multiple earth of a billion black anthropocenes (Yusoff, 2018). As Chakrabarty (2012) points out: 
There is no 'humanity' that can act as a self-aware agent. The fact that the crisis of climate change will be routed through all our 'anthropological differences' can only mean that, however anthropogenic the current global warming may be in its origins, there is no corresponding 'humanity' that in its oneness can act a political agent. (p.15).

There are differentiated life-lines in the event of the cosmocolossus. As Yusoff (2018) states: "Seeking to monumentalize Anthropocene history is an attempt to reclaim an "innocence" around this geohistory ... To be included in the "we" of the Anthropocene is to be silenced by a claim to universalism that fails to notice its subjugations ..." (Yusoff, 2018, p. 11-12). Yet there is a disturbing digital life that does seem to occupy the globe - the digital is both what seems to connect these different localisms, and at the same time be a platform for spreading pan-human stupidity (de Freitas, 2018). Latour turned to digital ethnography in the 2000s to track this connectivity across online platforms, by partnering with the statistician Lépinay, and drawing on ideas from the $19^{\text {th }}$ century posthumanist Gabrielle Tarde (influential for Deleuze and Guattari as well) who argued for alternative ways of mobilizing quantitative methods. Tarde was an 1890 French writer who argued for a statistics that was less about forcing data to comply to pre-given models, and more about letting the data-vectors of miniscule everyday acts accumulate in big data sets from which models of behaviour and sociality emerge (de Freitas, 2016a). AI today is a big data enterprise, and new empiricisms are emerging alongside these habits of inquiry, as the earth becomes a massive digital sensor, cloaked in data clouds (Gabrys, 2016).

There is an urgency to Latour's tone throughout this book, a noticeable anxiety to his claims, as he dwells on the eco-politics and onto-epistemologies of "The ends of the world" (Danowski and Viveiros de Castro, 2017). All too aware that the Eurocentric vision of humanity is not how the diverse peoples of the earth will undergo the Anthropocene, he is focused on 'terrans' as earth dwellers of all kinds. Concerned that many are moving along

like sleepwalkers, oblivious to the destruction writ by the flow of capital, Latour asks that his readers consider our ecological crisis as "a generalized state of war" (Latour, 2017, p.73). He is not advocating for the kind of geo-engineering solution that aims to defeat an enemy combatant, but concerned with a passive melancholia that causes many to hide from the horrors of the day. Rather than speak of 'hope' (which is always haunted with a desire for the past) or passive despair, he asks that his reader discover new "forms" of the earth and different ways of experiencing the passage of time. Latour's arguments against human exceptionalism are always grounded in particular proposals for action, as he aims to give humans "a shape" or "morph humans into a more realistic image" (Latour, 2017, p. 110).

\section{Agency, animacy, and causality}

Latour argues that conventional renderings of science rest on a faulty concept of causality, which ascribes all the agency to the cause and none to the effect. The conventional "scientific worldview" has often been used reductively to deanimate matter, and over-animate human intellect. This image of science fails to accurately characterize the practice of science, and reflects instead a Modernist desire to dominate and colonize. This "causalist" approach keeps all the action in the 'stimulus', as though action was always sourced from a unity, with the result of deanimating that which undergoes the intervention. This is the fantasy of control - the desire that there will be no surprises, no feed-back loops, no reciprocal touch. By de-animating the non-human and over-animating the human, the Moderns fail to 
encounter an earth populated with animated agents (Haraway, 2016). Worse still, this approach de-dramatizes the unfolding of events and the course of time, so that the future is made entirely predictable and subjected to the force of the 'present'. To buck the causalist plot is to live in a world where future agents (typically demoted as consequences and effects) signify and bring their existence retro-actively into the present. Shedding our attachment to causes that literally control all the action would entail queering time as we know it. This demands a new kind of causality which tracks the reciprocal mutations of the metamorphic zone, linking animacies and agencies across times in new ways.

Such thinking runs counter to conventional images of the scientific method which remain tied to a Newtonian notion of cause-effect. If the Western scientific revolution begins with Galileo, looking through the telescope and exclaiming, against the ontology and dogma of his day, "Eppur si muove" ("and yet it moves"), today the West confronts an earth that is not only a moving sphere amongst many, but also an "active, local, limited, sensitive, fragile, trembling, and easily irritated envelope.” (Latour, 2017, p. 60). ${ }^{2}$ Galileo's earth had movement, but no behavior. The earth known as Gaia is instead fully situated, and "inflicts" on humans their return from the infinite realm of ideals back into the folds of the material finite world. Gaia has two fundamental features: it is made of agents that are neither de-animated nor otheranimated, and it is made of agents that are not prematurely unified in a single acting whole. Indeed, the composition of Gaia is profoundly unknown, shaped by an infinity of heterogeneous agencies and waves of action that have the potential to defy globalism. This is Latour's multiple earth.

Science must not de-animate the earth, but instead treat it as a being in disequilibrium, and attend to its color, smell, surface, texture, aging (death), etc. Gaia is not a figure of harmony. Her mythic origins portray her as a violent trickster. Latour inherits the figure of Gaia from James Lovelock and microbiologist Lynn Margolis, and their image of earth as a complex system and organism. This reliance on the ideas of Lovelock, however, raises the concern that the entire project operates under the confining concept of organism. Lovelock (1979) described the earth as a "super-organism" such that "the earth behaves as a selfregulating system, and ... the proper science for its study is physiology." Although Latour argues that Gaia outstrips any biological image of thought (and body), I am still wary of how the concept of organism drives this image of the earth. Gaian bio-geopolitcs has had huge impact on systems theory or what Clarke (2017) calls "systems counterculture" through the work of Francisco Varela and William Irwin Thompson, and continues to echo in the work of Esposito $(2008,2011)$ on biopolitics and immunity. But perhaps we need to consider quantum paradigms and other scientific shifts, during the Anthropocene, in our attempts to understand how a body - any body, be it an atom, human or planet - is formed, organized and coordinated under some other form or image of life, different from the organism. Karen Barad's work on the quantum paradigm is relevant here, as we reconsider causality and relationality in $21^{\text {st }}$ century scientific theories (Barad 2012a, 2012b; de Freitas, 2017b).

Moreover, I think there is a need to think beyond the conventions of biosocial research, and examine the way that digital methods raise questions of quantum life and quantum decision theory (de Freitas, 2018; de Freitas \& Sinclair, 2018).

The Anthropocene calls for a form of inquiry and engagement that is truly immanent. This would be a kind of immanence that would bring causality down into the mud of effects and consequences, a feed-back situation that might better reckon with human activity in the flesh. Immanence fuses the finite with the infinite, but not as theological eternity in finite

\footnotetext{
${ }^{2}$ Latour points out that the account of 'Galileo the renegade' is now used by climate skeptics when they attack the apparent consensus of climatologists.
} 
time, found in the religious doctrine of incarnation, and articulated in terms of an emanation of god in matter. Instead, Latour argues that immanence must be cause of itself. ${ }^{3}$ Reclaiming causality to be of the world and in the world (as cause of itself) demands that researchers rethink the event-nature of their research methods. The proposal that substance is "cause of itself" has a long history, and is linked to the ideas of Spinoza in Western philosophy.

Following Voegelin, Latour describes immanence in contrast to emanation. Emanation is linked to the dangerous idea of "immanentization of the transcendental", often found in the rhetoric of incarnation. The danger here is that incarnation is an act of immanentization that inserts the transcendent into the material as though saving the profane body - the material world is then recuperated, rescued for having a right to life, and then subject to pursuant crimes in the name of liberation and enlightenment. This kind of incarnation actually betrays the very idea of immanence. Moreover, the ruling affect is regret rather than joy. Dejection and melancholia come from not being able to think the end times within a history that carries on, not being able to accept a geostory that has multiple futures and multiple earths. Joy is the affective correlate of immanence. Beware those who deny this potential multiplicity as inhering in the world; beware even those that claim to grasp a spirit which emanates from matter if they also refuse to imagine a posthuman eternity. It's important that immanence not bear eternal definitive human value, but rather describe the eternal incorporation of a plualist, dynamic and open set of agencies that inhere in the world.

\section{Convoked authorities and posthuman diplomacies}

Latour's book is based on a prestigious lecture series hosted in Edinburgh on "Natural Religion", delivered in the past by the likes of Alfred Whitehead (in 1927) and Niels Bohr (in 1949). The lectures are an attempt to bring secular scientists together into diplomatic relations with other "convoked authorities" that go by some other name (i.e. religions). This approach frames 'collectives' more generally, according to that which is cared for (either fact or fiction). Achieved by way of its rituals, a collected people is convoked around that for which they are careful. Thus a collective or peoples or body will form around, for instance, a practice such as scientific inquiry, but also around a religious set of beliefs. This is not to say that science is simply another form of religion, but rather to recognize the pluralism of collective human practices as they rigidify.

Latour draws on the historian of religion Jan Assmann $(2010,2018)$ who recounts how the Mosaic zone of translation, prior to monotheism in the cosmopolitan meeting places of Mediterranean territories, involved a complex form of differentiation and mulitplicity. Rather than insist on a deity that was untranslatable and incommensurable with others encountered, Assmann explains how translation tables listed attributes, so that one could describe one's own passionate attachments in such a way that the other might begin to recognize their own. Your god is called $\mathrm{X}$ and mine $\mathrm{Y}$, but they might share some attributes (trickster, storm-maker, omniscient, etc). Latour advocates for a similar space of encounter and translation as a way to co-exist and better understand how people differ. Colebrook (2017) critiques this kind of all-consuming translation, whereby everything comes to relate to everything else. This early kind of mosaic culture was pluralistic because it thrived on a certain kind of engagement that ensured linkage or looping across borders, beliefs, and territories, but Latour doesn't adequately address the power differentials across these loops.

3 The Spinozan emphasis on substance as "cause of itself" captures the kind of philosophy of immanence characterized here. 
The argument is that in the context of pre-Christian Mediterranean pluralism, this cosmopolitan political diplomacy ensured civil peace in societies with multiple attachments.

But in today's context, dominant monotheistic religions operate differently. Latour critiques the relation of "faith" as an inadequate engagement with the world. Faith is indeed a heroic adventure (manly, hetero, Euro), since it must pursue spirit not through the assurances of the body and the encounter, but through a fragile uncertain gesture without ground (and typically through indirect priestly interpretation as well). He contrasts these kinds of religions with philosophies of immanence, where engagement and encounter are privileged over indirect representation. Faith peoples live in an epoch after the end of time, but engage their worldly gods and forces through mediated distance and/or salvation. This demands a tenuous communing with the real, since the real is lost in its actuality. Latour is at his best in this chapter when he reminds us of the active principle of life, and how "Faith is what grasps you; knowledge is what you grasp" (Latour, 2017, p. 203). The Moderns inherit the habit of faith, a detached relationship to the earth: "they have no sort of possible contact with the terrestrial, since they can see in it only the transcendent, which would be trying awkwardly to fold itself into the immanent." (Latour, 2017, p. 205).

This term terrestrial is crucial for setting aside the flawed relationships with the earth that we've inherited from the Moderns. For Latour (2017), "the terrestrial is immanence freed of immanentization." (p. 212). For Kaiser \& Thiele (2017), however, the term proves powerful in directing our attention to at least three aspects of this new order: "terrestrial as tool to think human existence emancipated from a divine order; terrestrial as tied to earth in view of the immanent realm of planetary existence; and terrestrial in the sf-mode as envisioning terran existences - as earthly critters, and thereby disrupting the structural verticality of heaven and earth and the anthropocentric fantasies of extraterrestrialism" (p. 427).

Latour proposes five key questions that must be posed to any peoples, no matter their status or location on earth, questions that must be posed and answered indifferent to the distinctions that many humans hold dear, including nature/culture and science/religion, and even language/matter. Any form of risky diplomacy amongst creatures naming themselves as human (however they define that) must begin with these questions and requests: (1) identify the "supreme authority" by which you believe you have been convoked (i.e. military power, god, scientific knowledge, sexuality), (2) describe what limits you are given as members of this group, (3) state what territory you believe you inhabit, (4) name the epoch in which you believe you live, and (5) explain the principle of organization that distributes agency across your networks. He suggests that posthuman diplomacy be pursued through some such exercise of post-human encountering, where competing parties might create a conversation that crosses radical divides, and where science and religion might find a way to communicate about their differences diplomatically.

This interview/encounter protocol is a powerful device for rethinking relationality in the Anthropocene. Question one emphasizes the need to name your authority and offers an important transparency for any diplomacy to begin. The identification of limits that curtail activity speaks to the necessity of rule of law, and to the responsibilities that any community or collective must respect. This emphasis on our embodied and collective limitations is precisely what helps us understand our relations of dependence. The reference to territory and epoch ensures that two peoples, initially unknown to each other, come to understand how they conceptualize their borders and their rights to 'occupy' a place at a given time, and also whether they think they are starting out, at the beginning of their formation, or perhaps that they are a chosen people that come 'after' some previous fall. If answered honestly (a big 'if), these questions might open up an opportunity for translation and understanding 
across radical differences. The proposal seems a tad rationalist in its trust in perfect translation, but the emphasis on power and limitation is notable. As Latour (2017) states repeatedly, "The earthbound have to explore the question of their limits" (p. 290-291). He emphasizes the finitude of the planet and of life: "To live in the time of the end is first of all to accept the finitude of the time that passes and to put an end to negligence." (Latour, 2017, p. 286). Sensitive to how idealisms have caused so much harm in the name of colonial salvation, Latour announces: "To rediscover meaning in the question of emancipation, we bave to free ourselves from the infinite." (Latour, 2017, p. 285).

\section{Time and space: Flows, spheres and loops}

So much hinges on the way a people conceptualize time, including their relationship to the future. What epoch do you believe you are in? How does your understanding of time impact the way you relate to the earth and others? Do you believe that you are in an indefinite present to which all other times lead? Or a time after 'the fall', where you must seek forgiveness? Or a time that feels the force of an unruly and unknown future feed-back loop? Latour notes that talk of the Anthropocene brings up talk of apocalypse and end times, and perhaps even a desire for the end of time. Moreover, "there is no doubt about this point: the West has landed on all other civilizations like an Apocalypse that has put an end to their existence." (Latour, 2017, p. 205). With total calm the Moderns inflict apocalypse on others, as though they had a right to 'the' earth. This kind of entitlement betrays the fact that the earth they claim is emptied of animacy, and therefore without adequate temporality. Ironically then, the earth is no longer terrestrial (spatial and temporal) in the Modernist fantasy of control: "there is nothing terrestrial about this Earth, since what is denied, precisely, is that it has a history, a historicity, a retroaction, capacities - in short, agency." (Latour, 2017, p. 207).

The dominant world religions today rip the definitive truth of temporal flow from the end times, so that one is always after the end, reprising and operating under orders of salvation. Under such conditions, ecological warnings go unheeded. "To these peoples, obviously, nothing serious can happen any longer, since they believe they have always been within the "end of history"' (Latour, 2017, p. 195). These are the moralistic who respond to climate science condescendingly that they have already passed to the other side, no longer of our world, having entered into the kingdom of God or some other space of detachment (which could be righteous or apathetic). They shrug and say that ecological disaster and the end of life on earth is part of the plan. For these people time has already ended, and there is no longer any meddling in temporal flow (no sharing in the metamorphic zone). This makes the earth without history, shielded from the passing of time. These are a people who are perhaps the best at negligence - always looking back or indirectly at the world, rather than engaged with it.

To fight this rampant negligence, the earthbound must reckon with "an end of time within time" (Latour, 2017, p. 194). In other words, the fact that time passes, that we undergo time, that we are always in a finite time of mortality, must be recognized, says Latour, even as one names the Anthropocene as the end times. This is an end that is encompassed in the world, because there is a "time of the end" that must be attended, but not a universal and singular "end of times" (Latour, 2017, p. 197). The earthbound are always recommencing, always uncertain about time's achievement, but equally certain about its historical flow. It is this awkward sense of history - paradoxical in some sense - that must be kept alive. To counter negligence and apathy, we must take responsibility for our science 
and religion, and we must recognize the limitations of our claims, to ensure that these claims do not subject the material world to a higher detached temporal order (a transcendent realm). Life after death must remain entirely terrestrial. ${ }^{4}$

In The new science of politics, Voegelin (1987) explores how the Western notion of 'the end times', conceived as part of religious discourse, actually denied the earth the experience of those 'end times'. In other words, the Moderns (be they bad transcendentalists of the scientific or religious kind) have broken the crucial bond with temporal historical flow. The Anthropocene is clearly a way to conceive the end times in the present, which makes it such a difficult and contested idea. The end, for Latour, is an achievement, a finitude, and only a revelation insofar as it is in and with time, "and especially with the passage of time as its necessary medium" (Latour, 2017, p. 197). He will offer a strange maxim: "What lasts forever lasts only through what does not last" (Latour, 2017, p. 197).

Questions regarding temporality are always linked to the politics of spatial imaginaries (Tuck et al, 2014). What are the spatial imaginaries that might do a better job engaging with a metamorphic zone that defies conventional temporal emplotment? A philosophy of immanence demands that res extensa be stretched through intensive dimensions, so that space becomes an "intensive spatium" (Deleuze \& Guattari, 1987). The term intensity is key for Latour as he reimagines the earth as a network rather than a sphere or globe: "We are still dealing with space, with the earth, with discovery, but it is the discovery of a new Earth considered in its intensity and no longer in its extension." (Latour, 2017, p. 290). Following Sloterdijk's $(2011,2016)$ work on Modernity, globalism and spheres, Latour critiques the form of the sphere in Enlightenment images of the planet. The sphere itself has constant curvature, and performs rounded, continuous, complete, perfectly symmetric and traversable knowledge. This masks the actual material practices of assembling such a spherical form, and it overcodes the multiple earths that exist.

Moderns adore the perfect sphere: "a sphere has no history, no beginning, no end, no holes, no discontinuities of any sort. It is not merely an idea but the very ideal of ideas." (Latour, 2017, p. 136). It is in the age of European expansion and colonial acquisition, when terrestrial navigation spreads the monosphere across the earth, and a "vulgar" and diminished globalization takes hold. It is this figure of the globe with a capital $G$ that must be interrogated, for how it is built, tended, traversed, inhabited, consumed, etc. Latour suggests that building a globe, "always amounts to reactivating a theological theme" whereby aims for encyclopedic knowledge, transcendence, being the chosen people, etc, are given a popular form. Latour continues, claiming that the danger of spheres is that they both demand and enable a "premature leap to a higher level by confusing the figures of connection with those of totality." (Latour, 2017, p. 130).

He pursues instead a multiple earth, a new shape for the planet that is less enthrall to globalism, a shape that is not a shape - based on the figure of the loop. The future depends on tracing the complex loops that compose the metamorphic zone. The loop is a movement that turns back on itself, a path or linkage that is cause of itself:

... we have to slip into, envelop ourselves within, a large number of loops, so that, gradually, step by step, knowledge of the place in which we live and of the

${ }^{4}$ I am conscious that this paper puts challenges on 'me', as to choosing particular pronouns and forms of address. Latour uses "we" often, purposely conjuring a collective. That collective is perhaps better characterized by "the earthbound". 
requirements of our atmospheric condition can gain greater pertinence and be experienced as urgent. The slow operation that consists in being enveloped in sensor circuits in the form of loops: this is what is meant by "being of this Earth" (Latour, 2017, p. 139).

With each passage through a loop, one increases sensitivities to the fragility of the multiple earth. Moving through loops is a way to refuse the global perspective, and remain down in the tangles - the job is to deploy instruments that further allow us to make visible and sensible these paths, and to detect these connections between diverse agencies. This increased sensitivity is about "detecting and responding rapidly to small changes." (Latour, 2017, p. 141). We witness here a new kind of "reflexivity" that brings with it an intensity, "woven loop after loop, reflexivity after reflexivity, instrument after instrument." (Latour, 2017, p. 143).

In Dark Ecology, Morton (2016) will emphasize the form of the strange form of the loop as well, when advocating a "knowing that knows itself. Knowing in a loop - a weird knowing. Weird from the Old Norse urth, meaning twisted, in a loop." (Morton, 2016, p.5). The concept of weird is used here as a marker of the loop. He goes on to claim that "ecological awareness is a loop because human interference has a loop form, and because ecological and biological systems are loops. And ultimately this is because to exist at all is to assume the form of a loop." (Morton, 2016, p.6). Morton slams "parochial" Euclidean geometry as "anthropocentric", and invested in a false image of "smooth homogeneous universality" (p. 12). Pursuing the form or figure of the loop, he suggests we consider the power of strange mathematical loops: "A strange loop is one in which two levels that appear utterly separate, flip into one another." (Morton, 2016, p.7). And then he turns to the Möbius strip, a nonorientable surface, to assist in developing a different spatial imaginary.

A focus on loops is also found in Latour's earlier work when he redefined sociology, not as "the science of the social" but as "the tracing of associations" in actornetwork-theory (Latour, 2005, p. 5). In many ways Latour remains, as Graham Harman (2010) said, "The prince of networks". He coined the term Actor Network Theory in the 1980s, before the internet had taken off, and before the term network came to be used for everything, watering down its meaning to the point where he became somewhat ambivalent about it's name, proposing instead work-net theory, to emphasize the labour involved in sustaining a network. Other titular candidates at the time of inception had been "meshwork" and "network of innovation" and "actant-rhyzome ontology", indicating his indebtedness to the ideas of Deleuze. These terms also speak more accurately to his later work on the complex computational meshwork that binds contemporary scientists to their subject matter (Latour, 2002, 2010, 2012).

For Latour, we must keep a check on the "sciences of the universe" or "nature-asuniverse" as this kind of approach will always lead us to the view from nowhere, whereby the earth simply becomes a globe consisting of resources to be mined. Wark (2017) suggests that Latour is incapable of dealing with simulations of totality, and this creates a fundamental weakness in his theory. Wark underscores the importance of mathematical modeling and simulations (of totality) that are at the heart of current climate science: "Through the fates of worlds modeled in computation, we have in outline the likely fates of the actual one. No amount of agential complexity or empirical complication really disturbs that big picture." (Wark, 2017, np). In my estimation, however, both Wark and Latour are working with inadequate philosophical conceptions of mathematics. I would argue that mathematics is 
fully within the metamorphic zone, and that abstractions must be studied for their material and agentic power as well (de Freitas, 2016b).

\section{Last words: Territory, conflict and peace}

Vocabularies of war and conflict have often been used by Latour, as with these opening remarks in his powerful 2004 essay Why has critique run out of steam? From matters of fact to matters of concern:

Wars. So many wars. Wars outside and wars inside. Cultural wars, science wars, and wars against terrorism. Wars against poverty and wars against the poor. Wars against ignorance and wars out of ignorance. My question is simple: Should we be at war, too, we, the scholars, the intellectuals? Is it really our duty to add fresh ruins to fields of ruins? Is it really the task of the humanities to add deconstruction to destruction? More iconoclasm to iconoclasm? What has become of the critical spirit? Has it run out of steam? Quite simply, my worry is that it might not be aiming at the right target (Latour, 2004, p. 225).

This essay targets those scholars battling each other across the humanities, in the name of critique, when there might be a more important battle in which they should engage. Latour continues to understand how the current situation be conceived as a kind of war. The global corporate "elite" are managing this war - allowing destruction and violence to carry on - achieved through a kind of globalization that reigns over all human conflicts (Latour, 2018). This particular brand of economic globalism effects a depoliticized ecology and a deanimated earth. Those of us who are comfortably rewarded by this arrangement, carry on like sleepwalkers, oblivious to the destruction. Under this Modernist regime, the earth is sacrificed. How does one climb out of a control state, rising up against the quiet policing that keeps this regime intact? In the current sleep-walking condition, indifferent to the ecological disasters in which we participate, Modernist desires and delusions continue to subject the deanimated earth, at global scales. Latour asks that we acknowledge there has been an ongoing war, and that there is no pure harmony with nature nor each other. He pursues a posthuman diplomacy as the alternative to war, a process of declaring limitations and dependencies, using the interview/encounter protocol discussed above:

Bringing out these limits is the only way to repoliticize ecology and to put an end, consequently, to the simple operations of conquest, land grabs, or pacification (Latour, 2017, p. 241).

A repoliticization of ecology involves recognizing the antagonistic relationality in which we are invested, and the need to reshape dependency relations. ${ }^{5}$ Gaia is the multiplication of sites where agencies proliferate, where conflicts and contested territory are recognized and diplomatically engaged. New digital wrappings of the planet, and the saturation of computational earth sensor data will have a hand in this new diplomacy (Gabrys, 2016).

5 Latour suggests in his 2018 book Down to earth that we might need to stop using the term "ecology", since ecology as a form of inquiry has in some fundamental sense failed to shift the paradigm, the way Karl Polanyi predicted in 1945 in The great transformation. 
Perhaps at this point, there is a need for various nomadic war machines so as to end the sleepwalking (Braidotti \& Bignalle, 2018; Deleuze \& Guattari, 1987). The earthbound must realize that the control state is a generalized state of war, in which negligence reigns. But it seems rather juvenile to imagine this war as a game of thrones (as Latour does), since that will surely circumscribe the possible kinds of diplomacy that can be deployed. Thinking outside these conventional tropes is needed. Gilbert et al (2012) draw on symbiotic Gaian principles to contest the very idea of 'host' and individual, a dialectic which haunts current neocybernetic images of the planet as home or mother; Clarke (2017) explains how somatic individuation (and the practice of immunity that defends a crown) is itself a cosmological evolved state of a more general entropic dispersion of matter. In this intergalactic perspective, a new posthuman peace might then be negotiated through a risky diplomacy that pursues an immanent and yet extra-terrestrial scientific practice. Most importantly for Latour, following Schmitt (2006, 2011), peace is to be invented and achieved, but cannot be assumed. It is a compositional peace, established through specific kinds of more-thanhuman diplomacy. The earthbound are left, in these end-times, to co-develop distinctive diplomatic practices along with other worlding processes, as we co-compose a multipleearth.

\section{References}

Alumkal, Antony. 2017. Paranoid Science: The Christian Right's War on Reality. New York: New York University Press.

Assmann, J. (2010). The price of monotheism. Trans. R. Savage. Stanford, CA: Stanford University Press.

Assmann, J. (2018). The invention of religion: Faith and covenant in the book of exodus. Princeton, NJ: Princeton University Press.

Avelar, I. (2013). Amerindian perspectivism and non-human rights. After/nativas 1,1-21. Available at http://alternativas.osu.edu/en/issues/autumn-2013/essays/avelar.html

Barad, K. (2012a). On touching: the inhuman that therefore I am. Differences: A Journal of Feminist Cultural Studies, 23(3), 206-223. Revised and republished in Power of Material/ Politics of Materiality edited by Susanne Witzgall and Kirsten Stakemeier, 153165.

Barad, K. (2012b). Nature's queer performativity. Women, gender and research, 1-2, 25-53.

Braidotti, R. \& Bignalle, S. (2018). Posthuman ecologies: Complexity and process after Deleuze. Rowman \& Littlefield.

Chakrabarty, (2012). Postcolonial Studies and the Challenge of Climate Change. New Literary History, vol. 32, no. 1, pp. 1-18.

Chakrabarty, D. (2014). Climate and capitalism: On conjoined histories. Critical Inquiry, 42, $1-23$. 
Clarke, B. (2017). Planetary immunity: Biopolitics, Gaia theory, the holobiont, and the systems counterculture. In General ecology: The new ecological paradigm. (Ed. Erich Horl with James Burton). Bloomsbury Press. 193-216.

Colebrook, C. (2017). Essays on extinction. Open Humanities Press. Creative Commons. http://www.openhumanitiespress.org/books/titles/sex-after-life.

Coole, D., \& Frost, S. (2010). New materialisms: Ontology, agency, and politics. Durham, NC: Duke University Press.

Danowski, D. \& Viveiros de Castro, E. (2017). The ends of the world. (Trans. R. Nunes). Cambridge, UK: Polity Press.

de Freitas, E. (2016a). The new empiricism of the fractal fold: Rethinking monadology in digital times. Cultural Studies - Critical Methodologies, 16(2), 224-234.

de Freitas, E. (2016b). Number sense and calculating children: Multiplicity, measure and Mathematical monsters. Discourse: Studies in the Cultural Politics of Education, 37(5), 650661.

de Freitas, E. (2017a). Non-human findings from the laboratory of speculative sociology, Minnesota Review, 88, 116-126

de Freitas, E. (2017b). Karen Barad's quantum ontology and posthuman ethics: Rethinking the concept of relationality. Qualitative Inquiry.

de Freitas, E. (2018). The biosocial subject: Sensor technology and worldly sensibility. Discourse: Studies in the Cultural Politics of Education, 39 (2), 292-308.

de Freitas, E. \& Sinclair, N. (2018). The quantum mind: Alternative ways of reasoning with uncertainty. Canadian Journal of Science, Mathematics and Technology Education, 18(3), 271 283.

Deleuze, G. \& Guattari, F. (1987). A thousand plateaus: Capitalism and schizophrenia (Trans. B. Massumi). Minneapolis: University of Minnesota Press.

Drummond, C. \& Fischhoff, B. (2017). Individuals with greater science literacy and education have more polarized beliefs on controversial science topics. Proceedings of the National Academy of Sciences, 114 (36) 9587-9592. DOI:10.1073/pnas.1704882114.

Esposito, R. (2008). Bios: Biopolitics and philosophy. (Trans. T. Campbell). Minnesota: University of Minnesota Press.

Esposito, R. (2011). Immunitas: The protection and negation of life. (Trans. Z. Hanafi). Malden, MA: Polity Press. 
Gabrys, J. (2016). Program earth: Environmental sensing, technology and the making of a computational planet. Minneapolis: University of Minnesota Press.

Gauchat, G. (2012). Politicization of Science in the Public Sphere: A Study of Public Trust in the United States, 1974 to 2010. American Sociological Review, 77(2), 167-187.

Gilbert, S.F., Sapp, J. \& Tauber, A.I. (2012). A symbiotic view of life: We have never been individuals. The Quarterly Review of Biology, 87 (4), 325-41.

Hamilton, C. (2010). Requeim for a species: Why we resist the truth about climate change. New York: Routledge.

Haraway, D. J. (1988). Situated knowledges: The science question in Feminism and the privilege of partial perspective. Feminist Studies 14(3): 575-599.

Haraway, D. J. (2016). Staying with the trouble: Making kin in the Chthulucene. Durham, NC: Duke University Press.

Harman, G. (2010). Towards speculative realism: Essays and lectures. Winchester, UK: Zero Books.

Kaiser, B.M. \& Thiele, K. (2017). Terrestrial. In Rosi Braidotti \& Maria Hlavajova (Eds.), Posthuman glossary. Bloomsbury Academic.

Latour, B. (1987). Science in action: How to follow scientists and engineers through society. Cambridge, US: Harvard University Press.

Latour, B. (1988). The pasteurization of France (Trans. A. Sheridan \& J. Law). Cambrdige, US: Harvard University Press.

Latour, B. (2002). Gabriele Tarde and the end of the social. In Patrick Joyce (Ed.) The Social in Question: New Bearings in History and the Social Sciences. London: Routledge. $117-132$

Latour, B. (2004). Why has critique run out of steam? From matters of fact to matters of concern. Critical Inquiry, 30, 225-248.

Latour, B. (2010). Tarde's idea of quantification. In Matei Candea (Ed.), The social after Gabrielle Tarde: Debates and assessments. New York: Routledge. 147-164.

Latour, B. (2012). The whole is always bigger than its parts - a digital test of Gabrielle Tarde's monads. The British Journal of Sociology, 63 (4), 590-615.

Latour, B. (2005). Reassembling the social: An introduction to actor-network-theory. Oxford, UK: Oxford University Press.

Latour, B (2017). Facing Gaia: Eight lectures on the new climatic regime. Cambridge: Polity Press. 
Latour, B. (2018). Down to earth: Politics in the new climatic regime. Cambridge, UK: Polity Press.

Lovelock, J. (2000/1979]. Gaia: A New Look at Life on Earth (3rd ed.). Oxford University Press.

Moore, J. W. (2015). Capitalism in the web of life. Brooklyn, NY: Verso Books.

Morton, T.. (2016). Dark ecology. NY: Columbia University Press.

Parikka, J. (2015). The anthrobscene. Minnesota University Press.

Povinelli, E. A. (2016). Geontologies: A requiem for late liberalism. Duke University Press.

Schmitt, C. (2006). The nomos of the earth in the international law of jus publicum Europaeum. Trans. G.L. Ulmen. Telus Press Publishing.

Schmitt, C. (2011). Writings on war. Trans. T. Nunan. Cambridge: Polity Press.

Sloterdijk, P. (2011). Bubbles: Spheres Volume I. Semiotexte. MIT Publishing.

Sloterdijk, P. (2016). Foam: Spheres Volume III. Semiotexte. MIT Publishing.

Stengers, I. (2015). In catastrophic times: Resisting the coming barbarism. (Trans. A. Goffey). Paris, FR: Open Humanities Press/Meson Press.

Stengers, I. (2018). Another Science is Possible: A Manifesto for Slow Science. London: Polity Press.

Tsing, A. (2017). The mushroom at the end of the world: On the possibility of life in capitalist ruins. Princeton: Princeton University Press.

Tuck, E., McKenzie, M., \& McCoy, K. (2014). Land education: Indigenous, post-colonial, and decolonizing perspectives on place and environmental education research. New York, NY: Routledge.

Verlie, B. (2017). Rethinking climate education: Climate as entanglement. Educational Studies: A journal of the American Educational Studies Association, 53(6), 560-572.

Voegelin, E. (1987). The new science of politics: An introduction. Chicago: University of Chicago Press.

Wark, M. (2017). Bruno Latour: Occupy Earth. Accessed on Feb. 25, 2019. Available at https://www.versobooks.com/blogs/3425-bruno-latour-occupy-earth

Yusoff, K. (2018). A Billion Black. Anthropocenes or None. University of Minnesota Press. 